\title{
DESIGN AND CONSTRUCTION OF SMALL HYDRO POWER PLANTS ON THE NISAVA RIVER
}

Vicko Letica ${ }^{1}$

UDK: 627.8(497.11)

DOI: $10.14415 /$ konferencijaGFS2021.23

Summary: Gravity concrete, fill Dams and appurtenant structures are located on Nisava River. Small HPP "Vrgudinac" and HPP "Crveni breg", are a run-of-river-plant with dam constructed at the river bed and the power house located at the river bank. The maximum heights of the dams are $13.00 \mathrm{~m}$ and $13.70 \mathrm{~m}$. The maximum water head, with closed gates, is $4.60 \mathrm{~m}$. Both HPPs were put into the operation in the period from 2017 to 2019. As far as it is known, these are the first private HPP in Serbia, built in Serbia after the Second World War.

Keywords: dam, hydropower plant, concrete, levee, construction.

\section{DESCRIPTION}

HPP "Vrgudinac" is located on the river Nisava, about $2.5 \mathrm{~km}$ downstream to Bela Palanka, and HPP "Crveni Breg" is located downstream from HPP "Vrgudinac". These objects make possible the complex useas a part of the Nisava watercourse for electricity production, tourism and secondary activities. The total length of concrete structures, which include parts incorporated into the fill dams is about $90.00 \mathrm{~m}$. The maximum height of the dam "Crveni Breg" is $13.70 \mathrm{~m}$, and the dam "Vrgudinac" is $13.00 \mathrm{~m}$. The maximum water head, with closed radial gates, is $4.60 \mathrm{~m}$, when the power house is in operation. The installed capacity of each hydropower plant is $1.6 \mathrm{MW}$. In order to increase the water head, the riverbed downstream of the dam profile was dug. These hydropower plants are located on the same river relatively close, with the same water head. Their concept and geometry are also relatively the same. The main difference is in the arrangement. On "Crveni Breg", the Power plant together with the Erection Bay and the Administrative building with a prefabricated roof are on the left river bank, while on "Vrgudinac" are on the right bank. The dams are structurally divided by expansion joints into five separate blocks. At dam "Vrgudinac", the connection of the left levee, which forms the accumulation, is realized with a concrete gravity block. Between this block and the overflow block, there is a gravity concrete block in which the fish ladder is placed. Next to the overflow block-spillway, which is located in the central part, is also a non-overflow block-machine house located. The erection bay is located in the body of the earthfill dam. The connection between the earthfill dam and the concrete gravity part is realized by the retaining walls. The administrative building is located next to the erection bay.

\footnotetext{
${ }^{1}$ Mr.dipl.gradj.inž., Beograd BRANE-HPP-WTP. d.o.o office@brane-hpp-wtp.com
} 
8.

МЕЂУНАРОДНА КОНФЕРЕНЦИЛА

Савремена достигнућа у грађевинарству 22-23. април 2021. Суботица, СРБИЈА

The connection between the dam and banks of the reservoir realized through the levees which form the border of the reservoir.

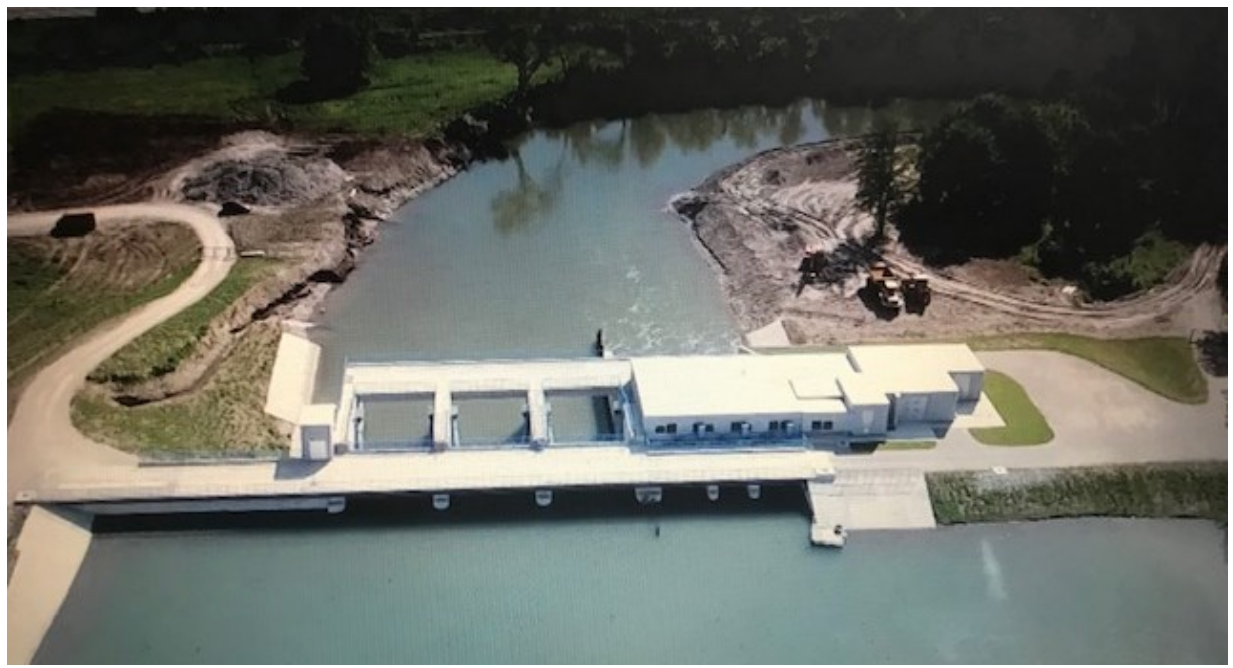

Figure 1. HPP "Vrgudinac"

The fill dams are located on the sides of the river and make a connection with the upstream levees. The maximum height of the dam is $13.70 \mathrm{~m}$. The fill dam is earthfill type dam. In the central part there is a core, which is formed of impermeable material, with increased water-resistant characteristics, which have marl. The body of the dam is designed with incoherent material, with dam slopes ratio 1:2.5. The protection of the upstream slope of the dam with a gabion, $25.00 \mathrm{~cm}$ thick is designed.

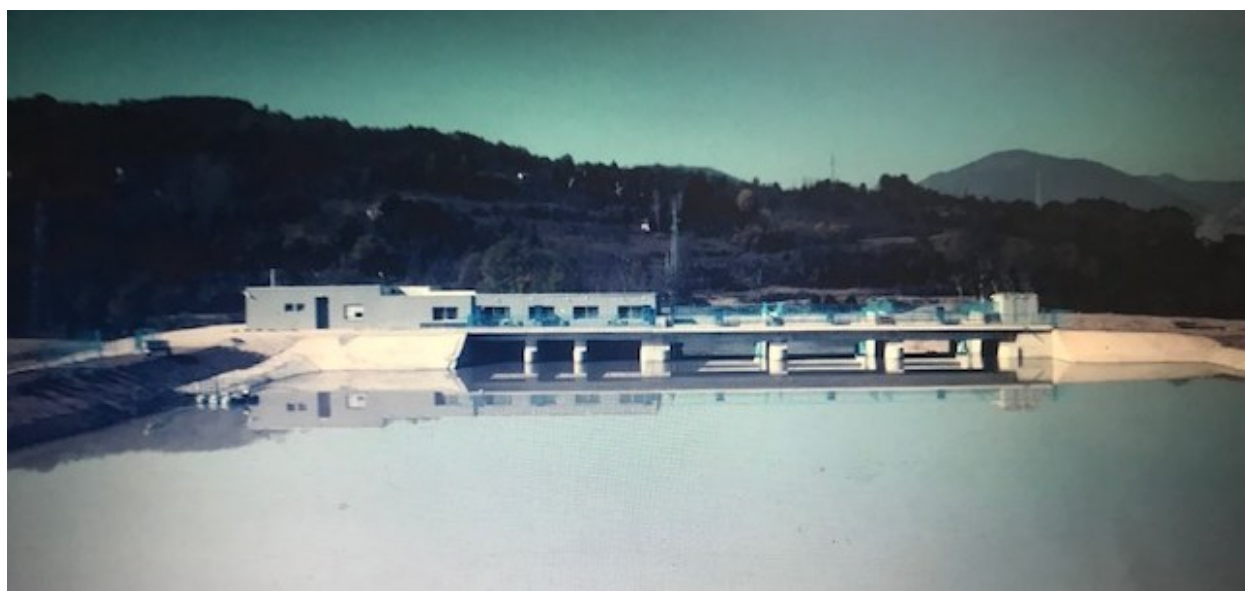

Figure 2. HPP "Crveni Breg"

In order to form an accumulation and provide flood protection for the new conditions, upstream levees on the left and right banks have been designed. The total length of the 
Contemporary achievements in civil engineering 22-23. April 2021. Subotica, SERBIA

upstream levees at HPP "Vrgudinac" is $2460.00 \mathrm{~m}$. The maximum height of the levee is $4.50 \mathrm{~m}$. On HPP "Crveni Breg", the total length of the right bank levee is $1050.00 \mathrm{~m}$. The total length of the left levee is $2046.00 \mathrm{~m}$. The levees on HPP "Crveni Breg" are formed from a combination of coherent and incoherent material, while levees on HPP "Vrgudinac" are formed only of coherent material. The width of the embankment in the crown is $4.00 \mathrm{~m}$, and the upstream and downstream slope is $1: 2.5$. On the upstream part of the foundation, is a concrete diaphragm that creates an impermeability between the concrete structures and an impermeable layer - marl. At the ends of this diaphragm, the continuation of protection against increased filtration is provided with an impermeable clay diaphragm $60.00 \mathrm{~cm}$ wide, and average depth of 4.00-7.00 m.

According to geological-geophysical investigations and projects, there is a Pliocene formation at the site of the dam, which is represented by marl sediments with very low values of shear parameters. All part of the concrete dam has been founded on the rock consisting of marl material of hard consistency. The earthfill dams and levees were founded on marl which is covered with a 5.00-7.00 m thick earth-gravel layer.

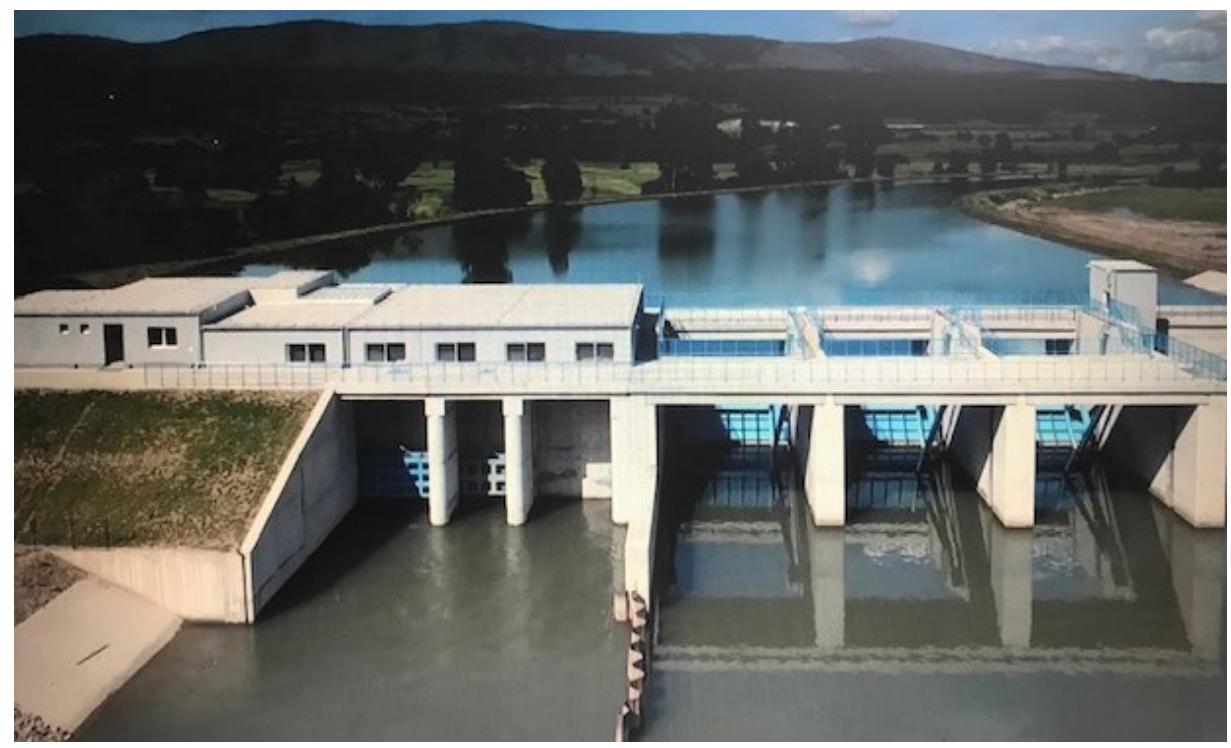

Figure 3. Downstream view

The spillway block generally consists of a slab and longitudinal vertical walls. The bridges are supported on the walls. The lower plate has dimensions of $25.50 \mathrm{~m}$ in the direction of the river and $31.50 \mathrm{~m}$ in the transverse direction, with thickness of $1.50 \mathrm{~m}$. The walls are $9.70 \mathrm{~m}$ height and $1.50 \mathrm{~m}$ thick. Due to the larger dimensions of the slab and walls, the concrete placing are precisely defined during construction in order to avoid the effects of temperature-heat and shrinkage. For that reason, the botom plate is divided into blocks 3$7.00 \mathrm{~m}$ width and length and $1.50 \mathrm{~m}$ height. The arrangement of the blocks corresponds to the chessboard. The time interval between adjacent blocks was minimum 7 up 21 days, depending on the position. Each wall is divided in the longitudinal direction by two "pass" sections 3.00 and $1.00 \mathrm{~m}$ wide. The three main concrete blocks were 6.00 to $9.00 \mathrm{~m}$ long. Each block was placed with a lift of up to $4.00 \mathrm{~m}$. 


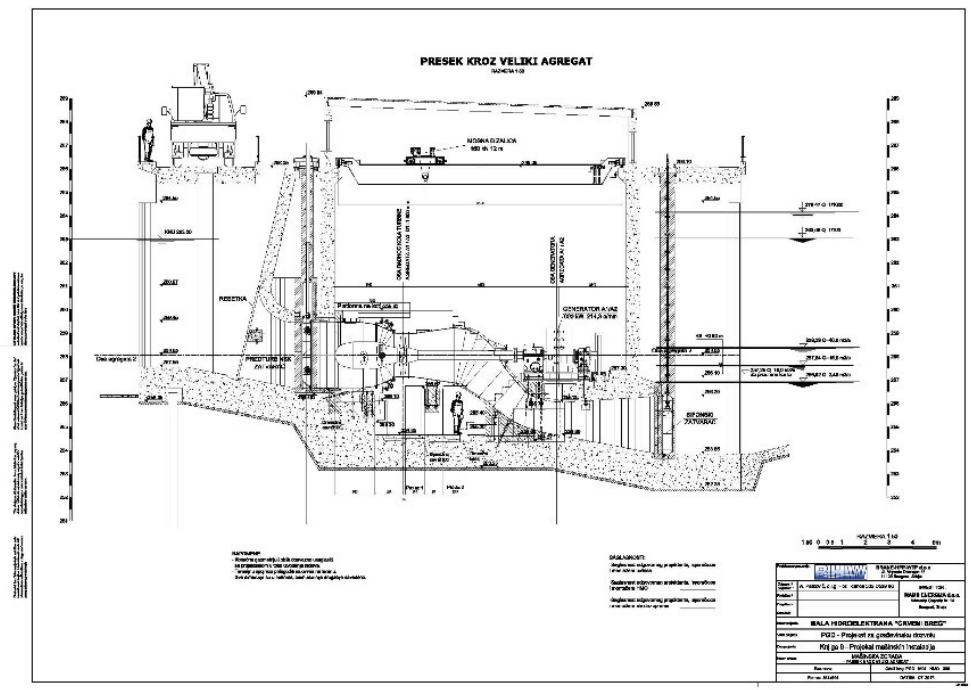

Figure 4. Power house - Deign

The block of a power house generally consists of a massive part, which is composed of a monolithic lower slab and longitudinal and transverse vertical walls. Upstream and downstream monolithic bridges are located at the highest level of the dam. The lower plate has dimensions of $25.50 \mathrm{~m}$ in the direction of the river and $16.60 \mathrm{~m}$ in the transverse direction, with a thickness of $1.50 \mathrm{~m}$. The walls are $0.60 \mathrm{~m}$ thick in the lower zones, while $0.35 \mathrm{~m}$ thick in the above structure.

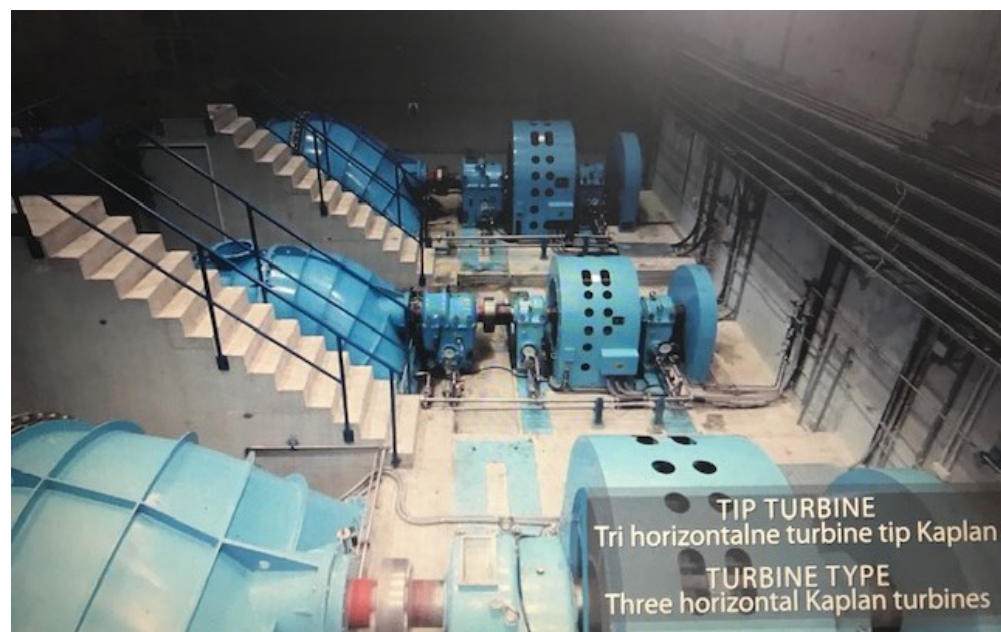

Figure 5. Power house - Operation

General stability of the structures was checked for usual, unusual and extreme load cases. For each of load cases necessary load combination was applied on the structure and coefficients of stability were calculated. Analysis of the stability against sliding, uplift and 
Contemporary achievements in civil engineering 22-23. April 2021. Subotica, SERBIA

overturning has performed. General stability analyses, in river flow direction, of the overflow-spillway part and the non-overflow-power house part were performed, where is shown that the structure will be stable for all operation regimes.

The dynamic analysis of the concrete parts of the dam structure was carried out in accordance with the Seismic Coefficient Method (Pseudo dynamic method applying the equivalent static load). For the Seismic Coefficient Method analysis values of coefficient peak ground acceleration were: $\mathrm{K}=0.0430$ for operating basis earthquake $\mathrm{Z} 1-\mathrm{OBE}$ and $\mathrm{K}=0.0715$ for maximal design earthquake Z2-MDE. Also, maximal compression stresses are at foundation contact level on downstream - toe part was checked.

Dimensioning and proportioning of concrete elements was performed according to the standard BAB 87. Dimensioning of steel elements was performed according to the Rules and Standards for steel structures. The control of the crack opening width was calculated according to the Russian SNIP norms.

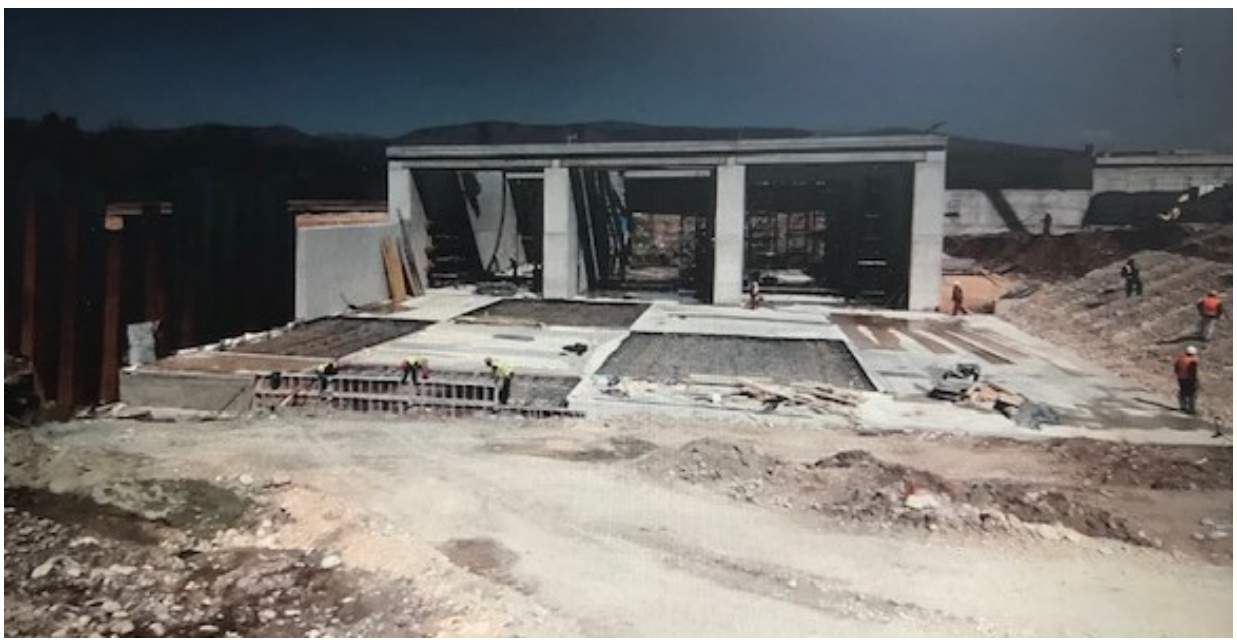

Figure 6. Construction stage

All massive structures were made with hydraulic concrete class MB 30, which was obtained with a mix of about $350 \mathrm{~kg} / \mathrm{m}^{3}$ cement Holcim CEM III / B-32.5N-LH / SR, aggregates, water and additives in the form of plasticizers and superplasticizers. For sensitive zones, concrete class MB 40 was used, which was obtained with a mix of about $400 \mathrm{~kg} / \mathrm{m} 3$ cement CEM I-52,5R, aggregates, water, stone flour and additives in the form of hyper plastics and expanders. The maximum aggregate size for concrete was $40,00 \mathrm{~mm}$. Non-constructive elements, such as leveling layer, fillings, etc, are made with concrete class MB 15. In order to avoid the occurrence of cracked systems, the maximum temperature of concrete during placement was $25^{\circ} \mathrm{C}$. When this was not possible to achieve only with natural conditions, cooling with water, chillers and night placing were performed. In spillway sections where increased abrasion is expected, reinforced concrete is reinforced by the addition of steel fiber in the amount of $40.00 \mathrm{~kg} / \mathrm{m}^{3}$. Expansions joint are provided with PVC waterstops, and bituminous coating. Swell strips are placed at the place of construction joints where the highest water pressure is expected. Steel hot-rolled reinforcement grade B500B was used, with minimum yield stress $500 \mathrm{MPa}$ (diameter 8 to 
Савремена достигнућа у грађевинарству 22-23. април 2021. Суботица, СРБИЈА

$36 \mathrm{~mm})$. The roof of the power house was constructed with the prestressed prefabricated concrete slabs $0.30 \mathrm{~m}$ thick and $1.20 \mathrm{~m}$ wide, with a slope of $4 \%$.

Approximate quantities of material for HPP „Crveni Breg“ are as follows. A total of $94000.00 \mathrm{~m}^{3}$ of earth was excavated. Filling was performed with excavated material in the amount of $48000.00 \mathrm{~m}^{3}$, and with coherent material in the amount of $44000.00 \mathrm{~m}^{3}$. A total of $2400.00 \mathrm{~m}^{2}$ gabions were constructed. A total of $7600.00 \mathrm{~m}^{3}$ of concrete were placed, and $650.00 \mathrm{t}$ of reinforcement were installed. Dilatations are provided with $100.00 \mathrm{~m}$ of waterstop. Due to the possible instantaneous and long-term settlement, the concrete structure is $5.00 \mathrm{~cm}$ higher.

Both HPP were designed, constructed and put into the operation in the period from 2014 to 2019. As far as it is known, these are the first private HPP in Serbia, built in Serbia after the Second World War.

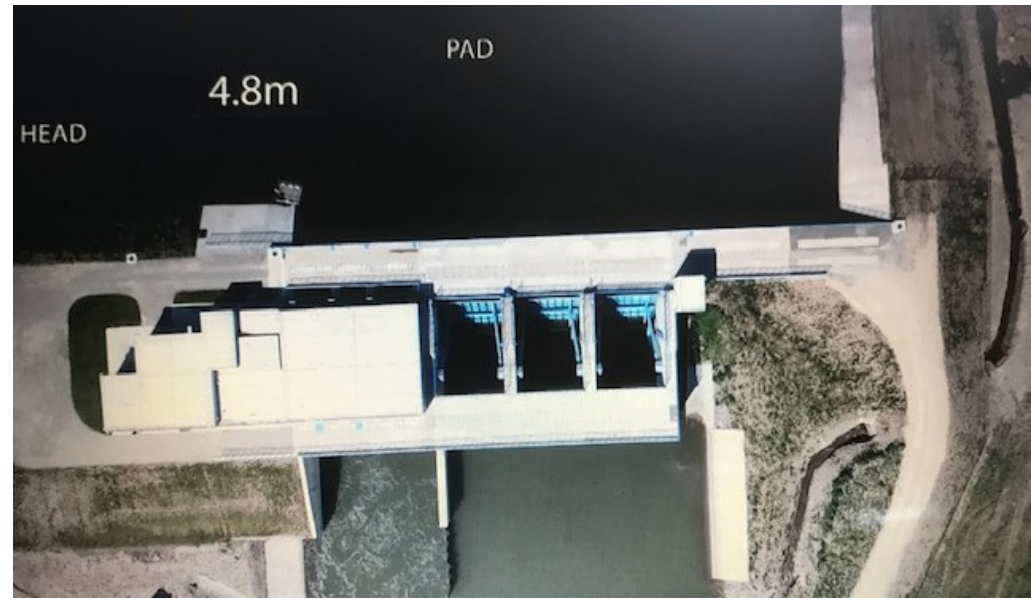

Figure 7. Perspective

\section{REFERENCES}

[1] „BRANE-HPP-WTP“ d.o.o. Beograd - „Mala hidroelektrana Crveni Breg 2017. godina. 